\title{
Optimization and evaluation of wheat germ oil extracted by supercritical $\mathrm{CO}_{2}$
}

\author{
By ShaoTong Jiang* and LiYa Niu
}

\author{
School of Biotechnology and Food Engineering, Hefei University of Technology, \\ 230009 Hefei, PR China \\ ( ${ }^{\star}$ Corresponding author: jiangshaotong@gmail.com)
}

\section{RESUMEN}

Optimización y evaluación del aceite de germen de trigo extraído por $\mathrm{CO}_{2}$ supercrítico.

Un diseño Box-Behnken combinado con metodología de superficie de respuesta (RSM) fue usado para optimizar los parámetros de extracción con fluido supercrítico (SFE) del aceite de germen de trigo. La calidad del aceite y de la harina residual obtenida por SFE y por extracción con solvente (SE) fue evaluada mediante su análisis porcentual, composición de ácidos grasos y actividad antioxidante. Un máximo rendimiento de aceite del $10.46 \%$ fue obtenido con las condiciones óptimas de 60-80 mesh de tamaño de partícula del germen de trigo; $4.37 \%$ contenido de agua; $30 \mathrm{MPa}$ de presión; $40^{\circ} \mathrm{C}$ de temperatura y $1.7 \mathrm{~h}$ de tiempo de extracción. El aceite obtenido por SFE mostró una capacidad atrapadora de radicales libres mucho mayor que el aceite obtenido por SE a la misma concentración. La composición de ácidos grasos del aceite SFE fue similar al aceite SE. El mayor contenido de proteínas $(34 \%)$ y de lisina $(2.47 \mathrm{~g} / 100 \mathrm{~g})$ fue encontrado en las harinas residuales obtenidas por SFE. Los resultados muestran que el aceite y la harina desengrasada obtenidas por SFE pueden ser atractivas y prometedoras fuentes nutricional en los alimentos.

PALABRAS-CLAVE: Aceite de germen de trigo - Extracción con dióxido de carbono supercrítico - Germen de trigo desengrasado - Metodología de superficie de respuesta.

\section{SUMMARY}

Optimization and evaluation of wheat germ oil extracted by supercritical $\mathrm{CO}_{2}$

A Box-Behnken design combined with response surface methodology (RSM) was used to optimize the parameters of supercritical $\mathrm{CO}_{2}$ extraction (SFE) of wheat germ oil. The quality of the oil and residual meal obtained by SFE and solvent extraction (SE) were evaluated from proximate analysis, fatty acid composition and antioxidant activity. A maximum oil yield of $10.46 \%$ was achieved under the optimal conditions of wheat germ particle size 60-80 mesh; water content $4.37 \%$; pressure $30 \mathrm{MPa}$; temperature $40^{\circ} \mathrm{C}$ extraction time $1.7 \mathrm{~h}$. The oil obtained by SFE showed stronger DPPH radical scavenging ability than SE oil at the same concentration. The fatty acid composition of SFE oil was similar to SE oil. Higher contents of protein (34.3\%) and lysine $(2.47 \mathrm{~g} / 100 \mathrm{~g})$ were found in the residual meal obtained by SFE. The results show that oil and defatted meal obtained by SFE can be promising nutritional sources for food.

KEY-WORDS: Defatted wheat germ - Response surface methodology - Supercritical carbon dioxide extraction Wheat germ oil.

\section{INTRODUCTION}

Wheat germ, a by-product of the wheat milling industry, is considered a natural source of highly concentrated nutrients. It contains about 52\% carbohydrate, $23 \%$ protein, $11 \%$ water, $10 \%$ oil and $4 \%$ ash. Wheat germ oil, as a special product with very high nutritional value, has the highest tocopherol content of all vegetable oils, up to about $2500 \mathrm{mg} / \mathrm{kg}$ (Schuler, 1990), in which $\alpha$-tocopherol represents around $60 \%$. In addition, wheat germ oil is rich in unsaturated fatty acids, mainly linoleic (18:2) and linolenic (18:3) (Wang and Johnson, 2001). Recently, wheat germ oil has been demonstrated to reduce plasma and liver cholesterol in animals and to delay aging. The defatted wheat germ, after extraction of valuable wheat germ oil, is a highly valued nutritive protein material. It contains about $30 \%$ protein and is rich in amino acids, especially the essential amino acids, such as lysine, methionine, and threonine, in which many cereals are deficient (Ge et al., 2000; Zhu et al., 2006). Therefore, wheat germ oil and defatted wheat germ are potential nutritious food supplements (Arshad et al., 2007; Ge et al., 2001; Matteuzzi et al., 2004).

Supercritical fluid extraction (SFE) is an efficient extraction method, which is non-explosive and non-toxic, leaving non-solvent residues. The oils extracted with this method do not need the traditional refining processes. In addition, SFE is a mild process which can avoid fatty acid oxidation and protein in defatted wheat germ denaturation. Therefore SFE has received increased attention as a promising alternative to conventional extraction methods over the last decades. There are several reports on the extraction of oil (Panfili et al., 2003; Shao et al., 2008; Zacchi et al., 2006), tocopherol (Ge et al., 2002) and antioxidants (Gelmez et al., 2009) from wheat germ by SFE. The effect of temperature, pressure and $\mathrm{CO}_{2}$ flow rate on oil yield (Shao et al., 2008), as well as the effect of pressure, temperature and extraction time on the antioxidant (phenolics and tocopherols) purity of the extracts obtained from roasted wheat germ have been studied. Although the SFE of wheat germ oil has been studied in these reports, the selection of the operating conditions is still an area of active research and needs to be studied 
further. Aside from the SFE condition, the material pretreatment such as water content and particle size are important factors which influence the extract yield (Ge et al., 2002). The evaluation of oils and defatted wheat germ obtained from SFE and SE is essential to study the relative merits of these techniques.

In the present study, the SFE of oil from wheat germ was examined. The effects of water content, the particle size of wheat germ and extraction parameters (pressure, temperature and extraction time) on oil yield were investigated. The extraction parameters were optimized using response surface methodology. The physical properties and chemical composition of oils and defatted wheat germ obtained by SFE and SE were compared.

\section{MATERIALS AND METHODS}

\subsection{Materials}

Raw wheat germ was obtained from Zhanyuan Corp (Hefei, China) and was carefully selected and cleaned to remove contaminats. The enzymes in the raw wheat germ were inactivated by heating for $30 \mathrm{~min}$ at $105^{\circ} \mathrm{C}$. Carbon dioxide (purity $99.9 \%$ ) was purchased from Henglong Gas Corp (Hefei, China). $\alpha$-tocopherol and 2,2-diphenyl-1-picrylhydrazyl (DPPH) were purchased from Sigma Chemical Co. (St. Louis, MO, USA). The methanol used for VE analysis and the hexane used for GC-MS analysis were of HPLC grade purchased from Guoyao Chemical Reagent Co., Ltd.(Chengdu, China). All other reagents were of analytical grade.

\section{2. methods}

\section{SFE procedure}

The SFE of wheat germ oil was performed on an HA121-50-01C device (Huaan Supercritical Fluid Extraction corp., Nantong, China), described in detail by WEI et al. (2009), using carbon dioxide as solvent. Wheat germ samples $(150 \mathrm{~g})$, with the chosen particle size and water content, were loaded into the extraction vessel. Carbon dioxide from a cylinder was passed through a chiller kept at $2^{\circ} \mathrm{C}$ and pumped into the extractor by a highpressure pump. The pressure and temperature were controlled to an accuracy of $\pm 0.5 \mathrm{MPa}$ and $\pm 0.5^{\circ} \mathrm{C}$, respectively. The flow rate of $\mathrm{CO}_{2}$ was controlled at $20 \mathrm{~kg} / \mathrm{h}$ for all experiments. After each extraction, the oil was collected in the first separator while water and volatile components were recovered in the second one. The amount of extracted oil was determined gravimetrically after collection and the wheat germ oil yield is expressed as percent weight.

\section{Experimental design for RSM of SFE}

RSM with three variables and three levels was applied to optimize the parameters for SFE processing of wheat germ oil. The extraction temperature $\left(X_{1}\right)$, extraction pressure $\left(X_{2}\right)$ and extraction time $\left(X_{3}\right)$ were independent variables studied to optimize the oil yield $(Y)$. The independent variables were coded for appraisal of the factors. Uncoded and coded values of the variables are given in Table 1. The levels of the parameters were based on preliminary experimental results. All experiments were carried out in a randomized order. A second-order polynomial regression model was used to express $Y$ (oil yield) as a function of the independent variables as follows: $Y=\beta_{0}+\beta_{1} X_{1}$ $+\beta_{2} X_{2}+\beta_{3} X_{3}+\beta_{12} X_{1} X_{2}+\beta_{13} X_{1} X_{3}+\beta_{23} X_{2} X_{3}+$ $\beta_{11} X_{1}^{2}+\beta_{22} X_{2}^{2}+\beta_{33} X_{3}^{2}$ The data collected from the SFE tests were analyzed using a response surface analysis procedure (Design-Expert 7.0Trial, StateEase, Inc., Minneapolis MN, USA).

\section{SE procedure}

A conventional method of Solvent extraction (SE) was performed to compare the extraction performances with SFE. Raw wheat germ (100g) was extracted using petroleum ether $(\mathrm{v} / \mathrm{w}=5: 1)$ as the solvent at room temperature for $24 \mathrm{~h}$, evaporated at $60^{\circ} \mathrm{C}$ to remove the solvent and then the oil was obtained.

\section{Proximate analysis of wheat germ oil and defatted meal}

Acid value, iodine value, peroxide value, saponification value, unsaponifiable matter, phospholipids and moisture of the oil samples were determined according to the AOCS methods (AOCS, 2009). Moisture, protein, fat, ash, fiber and total sugar of the defatted meal samples were

Table 1

Uncoded and coded levels of independent variables used in the RSM design

\begin{tabular}{lccccc}
\hline \multirow{2}{*}{ Variables } & \multicolumn{3}{c}{ Symbols } & \multicolumn{3}{c}{ Levels $^{*}$} \\
\cline { 2 - 6 } & Coded & Uncoded & $-\mathbf{1}$ & $\mathbf{0}$ & $\mathbf{1}$ \\
\hline Temperature $\left({ }^{\circ} \mathrm{C}\right)$ & $\mathrm{X}_{1}$ & $\mathrm{X}_{1}$ & 35 & 40 & 45 \\
\hline Pressure $(\mathrm{MPa})$ & $\mathrm{X}_{2}$ & $\mathrm{x}_{2}$ & 25 & 30 & 35 \\
\hline Extraction time $(\mathrm{h})$ & $\mathrm{X}_{3}$ & $\mathrm{X}_{3}$ & 0.5 & 1.5 & 2.5 \\
\hline${ }^{*} \mathrm{X}_{1}=\left(\mathrm{x}_{1}-40\right) / 5 ; \mathrm{X}_{2}=\left(\mathrm{x}_{2}-30\right) / 5 ; \mathrm{X}_{3}=\left(\mathrm{x}_{3}-1.5\right) / 1$ & & &
\end{tabular}


determined according to the AACC methods (AACC, 2004). The color of the oils was determined by lovibond tintometer (Shanghai Technologies, China). The total phenolic content (TPC) was measured using the Folin-Ciocalteu method according to the method described by Gelmez et al (2009). The $\alpha$-tocopherol content was determined using HPLC (Agilent Technologies, USA) according to the method described by Eisenmenger et al (2008). Fatty acids were analyzed by GC-MS (Agilent Technologies, USA) according to the method described by Wei et al (2009). The content of amino acids was determined with an automatic amino acid analyzer (835-50, Hitachi) according to the method described by Zhu et al (2006). Amino acid composition was reported as $g$ of amino acid $/ 100 \mathrm{~g}$ of protein. Three replicates were done for each analysis.

\section{Determination of antioxidant activity of wheat germ oil}

The wheat germ oil obtained under the optimal conditions was subjected to analysis of its antioxidant activity using a 2,2-diphenyl-1-picrylhydrazyl (DPPH) radical-scavenging assay. The method used was according to Lee et al (2007) with some modifications. A aliquot of oil $(0.5 \mathrm{ml})$ was mixed with $2.0 \mathrm{ml}$ of $0.004 \% \mathrm{DPPH}$ in isooctane. The mixture was shaken vigorously and immediately placed in the dark for $30 \mathrm{~min}$. The absorbance was monitored at $517 \mathrm{~nm}$ using a spectrophotometer (Fullerton, CA, USA). The experiments were performed in triplicate. Free radical scavenging activity from DPPH method was expressed in VE equivalents.

DPPH radical-scavenging activity $(\%)=\left(A_{B}-\right.$ $\left.A_{A}\right) / A_{B} \times 100$

Where $A_{B}$ and $A_{A}$ are the absorbance values of the blank and of the tested samples, respectively.

\section{RESULTS AND DISCUSSION}

\subsection{Effect of particle size of wheat germ on oil yield}

The effect of the particle size of raw wheat germ on oil yield is summarized in Table 2. A maximal

Table 2

Effect of particle size of wheat germ on oil yield ${ }^{\mathrm{a}}$

\begin{tabular}{cl}
\hline Sieving(mesh) & Oil yield(\%) \\
\hline no grinding & $6.44 \pm 0.15^{\mathrm{e}}$ \\
\hline $20-40$ & $7.13 \pm 0.10^{\mathrm{d}}$ \\
\hline $40-60$ & $8.10 \pm 0.13^{\mathrm{c}}$ \\
\hline $60-80$ & $9.57 \pm 0.09^{\mathrm{a}}$ \\
\hline $80-100$ & $9.01 \pm 0.17^{\mathrm{b}}$ \\
\hline
\end{tabular}

aSFE condition: water content $=4.37 \%$, pressure $=25 \mathrm{MPa}$; temperature $=55^{\circ} \mathrm{C}$; flow rate $=20 \mathrm{~kg} / \mathrm{h}$; extraction time $=1.5 \mathrm{~h}$. ${ }^{b}$ Each value indicates the mean value of three replicates; values with different letters are significantly different at $p<0.05$. oil yield of $9.57 \%$ was obtained with a particle size of $60-80$ mesh. Theoretically, the smaller the particle size, the faster the extraction. However, if the particle size is too small, the material in the extraction vessel may be accumulated and the pile density of the extracted material would increase, leading to weaker permeability of the extracted material, so the mass transfer coefficient would decrease. Therefore, the penetration of the oil into supercritical fluids is hampered and the oil yield decreases. Additionally, very fine particles often form a hard sample "flake" when high pressure is applied (Ge et al. 2002), which may also may decrease the oil yield. So a particle size of $60-80$ mesh was selected for subsequent tests.

\subsection{Effect of water content of wheat germ on oil yield}

Raw wheat germ was heated at $105^{\circ} \mathrm{C}$ for $30 \mathrm{~min}$ to inactivate enzymes and then for anther $30,60,90 \mathrm{~min}$ to obtain wheat germ with varying water contents. The effect of water content of wheat germ on oil yield is summarized in Table 3. The data suggests that oil yield increased as water content decreased, but when the water content was lower than $4.37 \%$, the oil yield decreased. This is because the proper amount of water could facilitate the penetration and diffusion of supercritical $\mathrm{CO}_{2}$ into the tissues of wheat germ and promote oil extraction. A similar phenomenon was found by $\mathrm{Ge}$ et al. (2002). A maximum oil yield of $9.57 \%$ was obtained with a water content of $4.37 \%$ and the water content of $4.37 \%$ was selected for subsequent tests.

\subsection{Optimization of SFE operating parameters}

The oil yield obtained from all the experiments along with the predicted oil yield are listed in Table 4 according to RSM design. Data from Table 4 suggests that the oil yield was higher with $30 \mathrm{~min}$ of extraction, which was similar to the effect described by Shao et al (2008).

Variance analyses of the factors studied for the response surface model are shown in Table

Table 3

Effect of water content of wheat germ on oil yield ${ }^{a}$

\begin{tabular}{cc}
\hline $\begin{array}{c}\text { Water content of wheat } \\
\text { germ }(\%, w / w)\end{array}$ & Oil yield $(\%)^{\mathrm{b}}$ \\
\hline 11.07 & $8.33 \pm 0.12^{\mathrm{c}}$ \\
\hline 7.26 & $9.35 \pm 0.11^{\mathrm{b}}$ \\
\hline 4.37 & $9.87 \pm 0.12^{\mathrm{a}}$ \\
\hline 1.46 & $9.28 \pm 0.10^{\mathrm{b}}$ \\
\hline
\end{tabular}

${ }^{a}$ SFE condition: particle size $=60-80$ mesh, pressure $=25 \mathrm{MPa}$; temperature $=55^{\circ} \mathrm{C}$; flow rate $=20 \mathrm{~kg} / \mathrm{h}$; extraction time $=1.5 \mathrm{~h}$. ${ }^{\mathrm{b}}$ Each value indicates the mean value of three replicates; values with different letters are significantly different at $p<0.05$. 
Table 4

Experimental scheme and results obtained from RSM

\begin{tabular}{cccccc}
\hline \multirow{2}{*}{ Runs } & \multicolumn{2}{c}{ Factor } & \multicolumn{2}{c}{ Extraction yield of oil (\%) } \\
\cline { 2 - 6 } & $\begin{array}{r}\text { Temperature } \\
\left(\mathbf{X}_{1},{ }^{\circ} \mathbf{C}\right)\end{array}$ & $\begin{array}{c}\text { Pressure } \\
\left(\mathbf{X}_{2}, \mathbf{M P a}\right)\end{array}$ & $\begin{array}{c}\text { Extraction time } \\
\left(\mathbf{X}_{3}, \mathbf{h}\right)\end{array}$ & Exp & Pred. \\
\hline 1 & 0 & -1 & -1 & 8.86 & 8.79 \\
2 & 0 & -1 & 1 & 9.40 & 9.48 \\
3 & 0 & 1 & -1 & 8.79 & 8.71 \\
4 & 0 & 1 & 1 & 9.26 & 9.33 \\
5 & -1 & 0 & -1 & 8.69 & 8.77 \\
6 & -1 & 0 & 1 & 9.03 & 8.96 \\
7 & 1 & 0 & -1 & 8.06 & 8.13 \\
8 & 1 & 0 & 1 & 9.31 & 9.24 \\
9 & -1 & -1 & 0 & 8.91 & 8.90 \\
10 & -1 & 1 & 0 & 9.46 & 9.46 \\
11 & 1 & -1 & 0 & 9.40 & 9.40 \\
12 & 1 & 1 & 0 & 8.60 & 8.61 \\
13 & 0 & 0 & 0 & 10.33 & 10.43 \\
14 & 0 & 0 & 0 & 10.41 & 10.43 \\
15 & 0 & 0 & 0 & 10.42 & 10.43 \\
16 & 0 & 0 & 0.50 & 10.43 \\
17 & 0 & 0.48 & 10.43 \\
\hline
\end{tabular}

5. From the statistical analysis, the model with a $P$-value of less than 0.0001 was highly significant, which implied that the model was suitable for this experiment. Meanwhile, the "lack of fit" was insignificant, the R-Squared was 0.9935, which indicated the model was in good agreement with the experimental results. The good agreement between the predicted and experimental values confirms the validity of the model.

Variance analyses of the factors studied for the coefficients of factors are given in Table 6. From the statistical analysis, extraction time and temperature significantly affected the oil yield; while the affect of pressure on oil yield was not significant. The interaction between temperature and pressure and temperature and extraction time significantly affected the oil yield; while the interaction between pressure and extraction time did not. All the second-order terms $\left(X_{1}^{2}, X_{2}^{2}, X_{3}^{2}\right)$ affected the oil yield significantly.

The coefficients of independent variables determined for the second-order polynomial model for the oil yield are given below:

$$
\begin{gathered}
Y_{1}=10.43-0.09 X_{1}-0.057 X_{2}+0.33 X_{3}- \\
-0.34 X_{1} X_{2}+0.23 X_{1} X_{3}-0.018 X_{2} X_{3}-0.82 X_{1}^{2}- \\
-0.52 X_{2}^{2}-0.84 X_{3}^{2}
\end{gathered}
$$

Where $Y$ is the extraction yield (\%), $X_{1}$ is the extraction temperature $\left({ }^{\circ} \mathrm{C}\right), \mathrm{X}_{2}$ is the extraction pressure $(\mathrm{MPa})$ and $\mathrm{X}_{3}$ is the extraction time $(\mathrm{h})$.

Table 5

Analysis of variance of regression parameters for the response surface model

\begin{tabular}{lccccc}
\hline \multicolumn{1}{c}{ Source } & Sum of squares & $\begin{array}{c}\text { Degree } \\
\text { of freedom }\end{array}$ & Mean Square & F-value & $\boldsymbol{P}_{\text {-value }}{ }^{\text {a }}$ \\
\hline Model & 9.252608 & 9 & 1.028068 & 119.5825 & $<0.0001$ \\
Linear & 8.358658 & 9 & 0.92874 & 207.7718 & $<0.0001$ \\
Quadratic & 7.652483 & 3 & 2.550828 & 296.7065 & $<0.0001$ \\
Lack of Fit & 0.0423 & 3 & 0.0141 & 3.154362 & 0.1481 \\
Pure Error & 0.01788 & 4 & 0.00447 & & \\
R-Squared & 0.993538 & & & & \\
\hline
\end{tabular}

\footnotetext{
${ }^{a} P<0.01$ highly significant; $0.01 \leq P<0.05$ significant; $P \geq 0.05$ not significant.
} 
Table 6

Regression coefficients of predicated second-order polynomial model for the response variables

\begin{tabular}{ccccr}
\hline Factor $^{\mathrm{a}}$ & Coefficient Estimate & Sum of Squares & F-value & $\boldsymbol{P}_{\text {-value }}{ }^{\mathrm{b}}$ \\
\hline $\mathrm{X}_{1}$ & -0.09 & 0.0648 & 7.537388 & 0.0287 \\
$\mathrm{X}_{2}$ & -0.057 & 0.02645 & 3.076604 & 0.1229 \\
$\mathrm{X}_{3}$ & 0.325 & 0.845 & 98.28847 & $<0.0001$ \\
$\mathrm{X}_{1} \times \mathrm{X}_{2}$ & -0.3375 & 0.45569 & 52.99726 & 0.0002 \\
$\mathrm{X}_{1} \times \mathrm{X}_{3}$ & 0.2275 & 0.20709 & 24.08067 & 0.0017 \\
$\mathrm{X}_{2} \times \mathrm{X}_{3}$ & -0.0175 & 0.001225 & 0.142489 & 0.7170 \\
$\mathrm{X}_{1} \times \mathrm{X}_{1}$ & -0.82025 & 2.8329 & 329.5146 & $<0.0001$ \\
$\mathrm{X}_{2} \times \mathrm{X}_{2}$ & -0.51525 & 1.11789 & 130.0224 & $<0.0001$ \\
$\mathrm{X}_{3} \times \mathrm{X}_{3}$ & -0.83525 & 2.93749 & 341.6766 & $<0.0001$ \\
\hline
\end{tabular}

${ }^{a} \mathrm{X}_{1}$ : temperature; $\mathrm{X}_{2}$ : pressure; $\mathrm{X}_{3}$ : extraction time. ${ }^{\mathrm{b}} P<0.01$ highly significant; $0.01 \leq P<0.05$ significant; $P \geq 0.05$ not significant.

A maximum oil yield of $10.46 \%$ was achieved under optimal conditions: pressure 30MPa; temperature $40^{\circ} \mathrm{C}$; extraction time $1.7 \mathrm{~h}$. Additional experiments in triplicate under these optimized extraction conditions were carried out. These triplicate experiments produced an average oil yield of $10.38 \%$, which concurred with the model prediction.

3D response surfaces plots were employed to determine the interaction of the extraction parameters effect on oil yield.

Figure. 1 shows the response surfaces showing the effect of temperature and pressure on oil yield at the fixed extraction time 1.5h. It was observed that the oil yield increased with the rise in pressure, when the temperature was lower than $42.5^{\circ} \mathrm{C}$. If the temperature was higher than $42.5^{\circ} \mathrm{C}$, the oil yield decreased with the rise in pressure. This is because the increase in pressure led to an increase in the density of supercritical $\mathrm{CO}_{2}$. The results were consistent with those reported in another study (Shao et al., 2008). However, taking safety and economy into account, the pressure was not too high. On the other hand, the other components such as pigment would be extracted under high pressure, which could make the oil dark in color.

The influence of temperature on extraction was more difficult to predict than that of pressure because of its two counter effects on the oil yield (Zhang et al., 2010). First, the rise in temperature

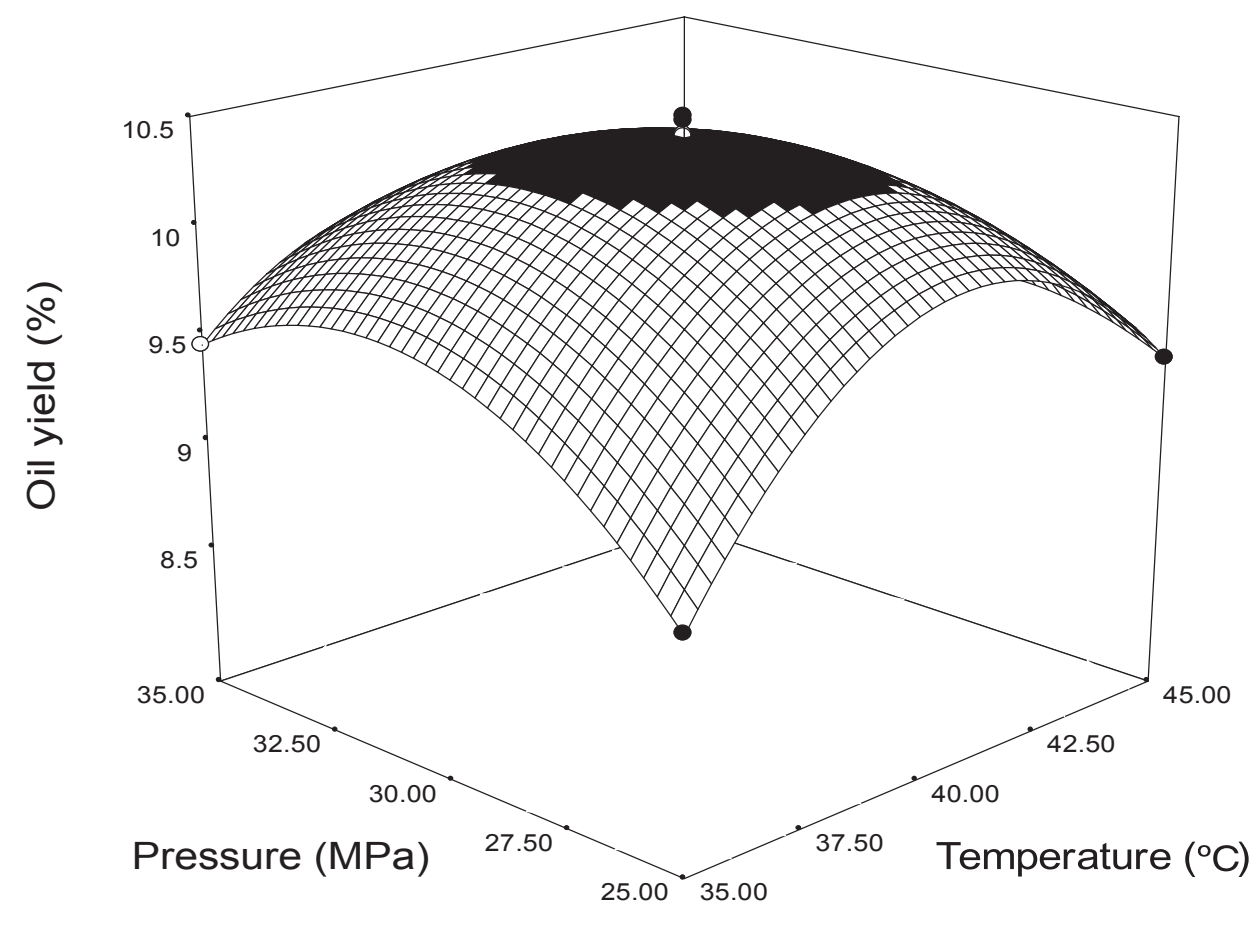

Figure 1

3-D plot of response surface for the effect of temperature and pressure on oil yield. 
decreased the density of supercritical $\mathrm{CO}_{2}$, which led to a decrease in oil yield. Second, the rise in temperature increased the vapor pressure of the solutes, which was advantageous for extraction. As presented in Fig. 1, the oil yield increased with the rise in temperature at an early stage of extraction. Similar results were observed in those reported in other studies (Wei et al., 2009; Zhang et al., 2010).

Figure. 2 was the response surfaces showing the effect of temperature and extraction time on oil yield at the fixed pressure of 30MPa. Extraction time was also an important factor affecting the oil yield. The oil yield did not continue to significantly increase until the extraction time was over $1.7 \mathrm{~h}$. However, prolonging the extraction time to over $2.0 \mathrm{~h}$ produced only a slight change in the oil yield.

\subsection{Physical and chemical characteristics of wheat germ oil}

The major fatty acid composition of wheat germ oil by different extraction methods is shown in table 7. The wheat germ oil was rich in polyunsaturated fatty acid, especially in linoleic acid. As can be observed, the fatty acid contents of wheat germ oil obtained from SFE were similar to those from SE.
Similar results were also reported in these studies (Eisenmenger et al., 2006; Piras et al., 2009; Shao et al., 2008).

The physical and chemical characteristics of wheat germ oil extracted by different methods are shown in Table 8. These results demonstrate that SFE could improve wheat germ oil quality, especially decreasing the acid value, peroxide value and color. This is because SFE, which proceeded with low pressure $(30 \mathrm{MPa})$, short extraction time $(1.7 \mathrm{~h})$ and low temperature $\left(40^{\circ} \mathrm{C}\right)$ without any toxic solvent, could mostly protect the bioactive components, in particular with the content of $\alpha$-tocopherol reaching $276.8 \pm 2.6 \mathrm{mg} / 100 \mathrm{~g}$. The petroleum ether was much less selective than $\mathrm{CO}_{2}$ in the extracted oil and produced an oil which contained some undesirable compounds (Piras et al., 2009).

\subsection{Antioxidant activity of wheat germ oil}

The antioxidant activities of wheat germ oil extracted with different methods were tested by 2,2-diphenyl-1-picrylhydrazyl (DPPH) radicalscavenging assay. Figure 3 . shows that in the rage of $1-50 \mathrm{mg} / \mathrm{ml}$, the wheat germ oil displayed a significant dose-dependency on the DPPH radical-

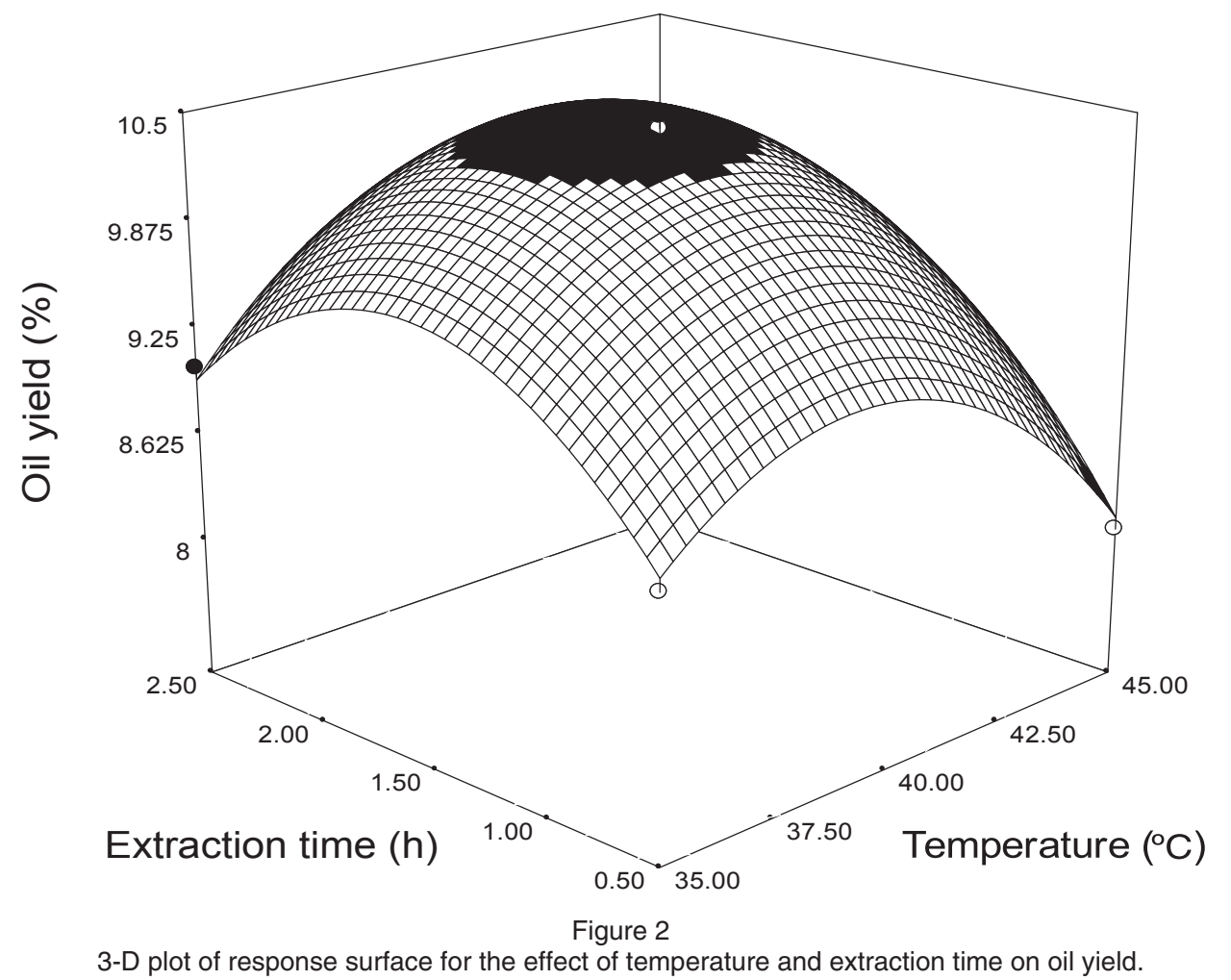

Table 7

Fatty acid composition of wheat germ oils extracted with different methods

\begin{tabular}{cccccccccc}
\hline Methods & $\mathbf{1 6 : 0}$ & $\mathbf{1 8 : 0}$ & $\mathbf{1 8 : 1}$ & $\mathbf{1 8 : 2}$ & $\mathbf{1 8 : 3}$ & Others & SFA & MUFA & PUFA \\
\hline SFE & 16.27 & 0.28 & 13.19 & 64.82 & 4.91 & 0.53 & 13.19 & 13.72 & 69.73 \\
\hline SE & 16.25 & 0.24 & 13.97 & 64.18 & 4.75 & 0.61 & 13.97 & 14.58 & 68.93 \\
\hline
\end{tabular}


Table 8

Physical and chemical characteristics of wheat germ oils extracted with different methods

\begin{tabular}{lcc}
\hline & SE & SFE \\
\hline Moisture & $0.68 \pm 0.02$ & $0.47 \pm 0.08$ \\
Color & & \\
$\quad$ Red index & $7.0 \pm 0.2$ & $6.1 \pm 0.3$ \\
$\quad$ Yellow index & $20 \pm 0$ & $20 \pm 0$ \\
Acid value $(\mathrm{mgKOH} / \mathrm{g})$ & $12.8 \pm 0.8$ & $9.1 \pm 0.2$ \\
Peroxide value $(\mathrm{mmol} / \mathrm{kg})$ & $2.95 \pm 0.04$ & $2.05 \pm 0.09$ \\
Saponification value $(\mathrm{mgKOH} / \mathrm{g})$ & $121.5 \pm 1.98$ & $169.3 \pm 1.52$ \\
lodine value $(\mathrm{gl} / \mathrm{l} / \mathrm{OOg})$ & $142.8 \pm 1.85$ & $149.1 \pm 1.34$ \\
Unsaponifiable $\mathrm{matter}(\%)$ & $3.34 \pm 0.05$ & $4.16 \pm 0.08$ \\
Phospholipids $(\%)$ & $5.76 \pm 0.07$ & $1.62 \pm 0.06$ \\
TPC (ugGAE/ml) & $4.02 \pm 0.05$ & $8.64 \pm 0.10$ \\
$\alpha$-tocopherol $(\mathrm{mg} / 100 \mathrm{~g})$ & $154.4 \pm 2.1$ & $276.8 \pm 2.6$ \\
\hline
\end{tabular}

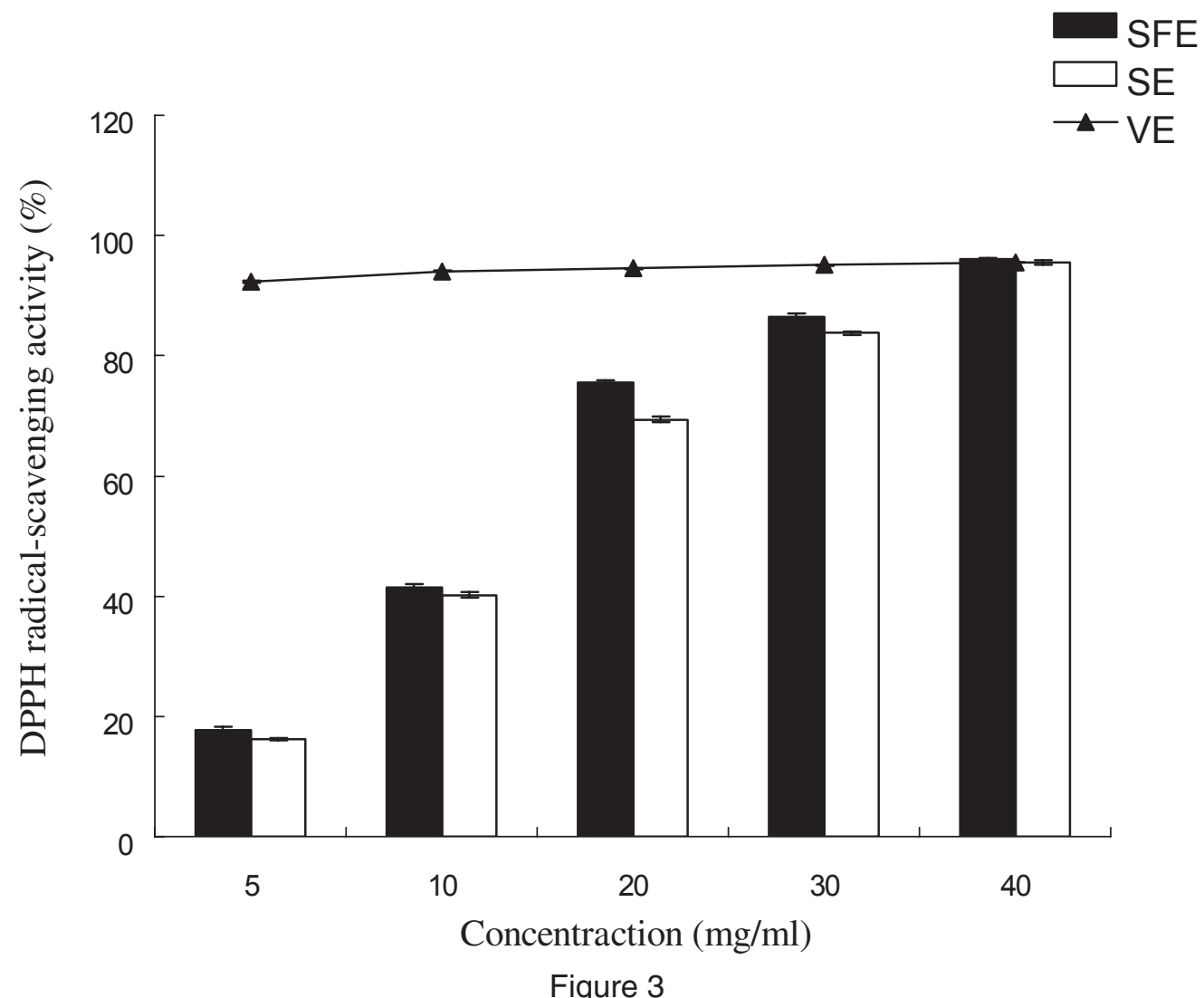

Antioxidant activity of wheat germ oil assessed by DPPH radical scavenging assay.

scavenging activity. Obviously, the antioxidant activity of wheat germ oil extracted by SFE is slightly stronger than that of SE. This is attributed to the different solubility of active components in the solvents and the supercritical carbon dioxide. When the concentration of oil was higher than $40 \mathrm{mg} / \mathrm{ml}$, the DPPH radical-scavenging activity in the oils reached $96.08 \%$, which corresponds to VE with the same concentration. The higher content of tocopherol and total phenolic compounds in the wheat germ oil, as well as the higher content of unsaturated fatty acid could account for the stronger antioxidant activity of the wheat germ oil extracted by SFE (Eisenmenger and Dunford, 2008). 


\subsection{Proximate analysis of defatted wheat germ}

In order to consider the possibility of using wheat germ as a protein food supplement, the quality of the defatted wheat germ was also evaluated.

The proximate analyses of raw wheat germ and defatted wheat germ with different methods are given in Table 9. The data show that SFE may significantly decreas the water content and lipid content of the defatted wheat germ, which could prevent auto-oxidative processes and improve the shelf life of this byproduct. Ash, fiber, and protein contents above all increased in defatted wheat germ, giving an additional nutritional value to the defatted wheat germ. The protein content was up to $32.4 \%$ and $34.3 \%$ in the defatted wheat germ, making the defatted wheat germ one of the most attractive and promising sources of vegetable proteins.

As can be observed in Table 10, the amino acid composition did not change significantly among the different extraction methods. The most striking was the abundance of lysine, which is the first limiting amino acid in the grain(Ge et al., 2000). However, cysteine was lower in wheat germ. In light of these results, defatted wheat germ could be used as a promising by-product for food supplements.

\section{CONCLUSIONS}

A second-order polynomial model was sufficient to describe and predict the response variable of the

Table 9

Composition of raw wheat germ and defatted wheat germ with different methods

\begin{tabular}{cccc}
\hline & Raw wheat germ & SE & SFE \\
\hline Moisture (\%) & $12.78 \pm 0.7$ & $13.67 \pm 0.9$ & $0.47 \pm 0.03$ \\
Fat (\%) & $11.33 \pm 1.6$ & $3.45 \pm 0.07$ & $1.36 \pm 0.04$ \\
Ash (\%) & $4.51 \pm 0.05$ & $1.77 \pm 0.06$ & $1.83 \pm 0.06$ \\
Protein (\%) & $30.7 \pm 1.6$ & $32.4 \pm 2.1$ & $34.3 \pm 1.2$ \\
Fiber (\%) & $1.40 \pm 0.02$ & $1.77 \pm 0.04$ & $1.83 \pm 0.01$ \\
Total sugar(\%) & $11.59 \pm 1.3$ & $12.95 \pm 1.6$ & $17.3 \pm 2.5$ \\
TPC (mg/g) & $0.84 \pm 0.006$ & $0.70 \pm 0.01$ & $0.84 \pm 0.004$ \\
\hline
\end{tabular}

Table 10

Comparative amino acid profile of raw wheat germ and defatted wheat germ with different methods $(\mathrm{g} / 100 \mathrm{~g})$

\begin{tabular}{cccc}
\hline Amino acid & Raw wheat germ & SFE & SE \\
\hline Asp & 2.67 & 3.01 & 2.89 \\
Glu & 4.63 & 5.14 & 5.01 \\
Ser & 1.35 & 1.50 & 1.44 \\
His & 0.76 & 0.85 & 0.83 \\
Gly & 1.82 & 2.07 & 2.00 \\
Thr & 1.28 & 1.44 & 1.39 \\
Arg & 2.43 & 2.72 & 2.67 \\
Ala & 1.93 & 2.17 & 2.11 \\
Tyr & 0.66 & 0.76 & 0.73 \\
Cys & 0.23 & 0.24 & 0.22 \\
Val & 1.61 & 1.84 & 1.80 \\
Met & 0.47 & 0.49 & 0.49 \\
Phe & 1.19 & 1.32 & 1.29 \\
Ile & 1.04 & 1.18 & 1.17 \\
Leu & 1.99 & 2.23 & 2.18 \\
Lys & 2.17 & 2.47 & 2.40 \\
Pro & 1.93 & 2.15 & 2.09 \\
Total amino acids & 28.16 & 31.58 & 30.71 \\
\hline
\end{tabular}


oil yield for SFE of wheat germ oil. A maximal oil yield of $10.46 \%$ was achieved under the optimal conditions of wheat germ particle size 60-80 mesh; water content $4.37 \%$; pressure $30 \mathrm{MPa}$; temperature $40^{\circ} \mathrm{C}$; extraction time $1.7 \mathrm{~h} ; \mathrm{CO}_{2}$ flow rate $20 \mathrm{~kg} / \mathrm{h}$. Compared with the solvent extraction using petroleum ether, wheat germ oil obtained from SFE, contained more important bioactive components, with the content of $\alpha$-tocopherol reaching $276.8 \pm 2.6 \mathrm{mg} / 100 \mathrm{~g}$. And when the concentration of oil was $40 \mathrm{mg} / \mathrm{ml}$, the $\mathrm{DPPH}$ radical-scavenging activity in the oils reached $96.08 \%$, which corresponds to VE with the same concentration. On the other hand, the defatted wheat germ obtained from SFE has high contents of protein and lysine, making it a promising natural source in food fortification.

\section{REFERENCES}

AOCS. 2009. Methods and recommended practices of the AOCS. American Oil Chemists Society, USA.

Arshad, M., Anjum, F., Zahoor, T.2007. Nutritional assessment of cookies supplemented with defatted wheat germ. Food Chem 102, 123-128.

AACC. 2004. Approved Methods of the AACC. American Association of Cereal Chemists, $10^{\text {th }}$ ed., Approved Medthod Committee,St Paul, MN.

Eisenmenger, M., Dunford, N. 2008. Bioactive components of commercial and supercritical carbon dioxide processed wheat germ oil. J. Am. Oil Chem. Soc. 85, 55-61.

Eisenmenger, M., Dunford, N., Eller, F., Taylor, S., Martinez, J. 2006. Pilot-scale supercritical carbon dioxide extraction and fractionation of wheat germ oil. J. Am. Oil Chem. Soc. 83, 863-868.

Ge, Y., Sun, A., Ni, Y., Cai, T. 2000. Some nutritional and functional properties of defatted wheat germ protein. J. Agric. Food Chem. 48, 6215-6218.

Ge, Y., Sun, A., ni, Y., Cai, T. 2001. Study and development of a defatted wheat germ nutritive noodle. Eur. Food Res. Technol. 212, 344-348.

Ge, Y., Yan, H., Hui, B., ni, Y., Wang, S., Cai, T. 2002. Extraction of natural vitamin $\mathrm{E}$ from wheat germ by supercritical carbon dioxide. J. Agric. Food Chem. 50, 685-689.
Gelmez, N., Kincal, N., Yener, M. 2009. Optimization of supercritical carbon dioxide extraction of antioxidants from roasted wheat germ based on yield, total phenolic and tocopherol contents, and antioxidant activities of the extracts. J. Super Fluids. 48, 217-224.

Lee, J., Chung, H., Chang, P., Lee, J. 2007. Development of a method predicting the oxidative stability of edible oils using 2, 2-diphenyl-1-picrylhydrazyl (DPPH). Food Chem. 103, 662-669.

Matteuzzi, D., Swennen, E., Rossi, M., Hartman, T., Lebet, V. 2004. Prebiotic effects of a wheat germ preparation in human healthy subjects. Food Microbiol. 21, 119-124.

Panfili, G., Cinquanta, L., Fratianni, A., Cubadda, R. 2003. Extraction of wheat germ oil by supercritical $\mathrm{CO}_{2}$ : Oil and defatted cake characterization. J. Am. Oil Chem. Soc. 80, 157-161.

Piras, A., Rosa, A., Falconieri, D., Porcedda, S., Dess, M., Marongiu, B.2009. Extraction of oil from wheat germ by supercritical $\mathrm{CO}_{2}$. Molecules 14, 2573.

Schuler, P. 1990. Natural Antioxidants Exploited Commercially, Food Antioxidants. Edited by B. Hudson, Elsevier.

Shao, P., Sun, P.L., Ying, Y.J. 2008. Response surface optimization of wheat germ oil yield by supercritical carbon dioxide extraction. Food Bioprod. Process 86(C3), 227-231.

Wang, T., Johnson, L. 2001. Refining high-free fatty acid wheat germ oil. J. Am. Oil Chem. Soc. 78, 71-76.

Wei, Z., Liao, A., Zhang, H., Liu, J., Jiang, S. 2009. Optimization of supercritical carbon dioxide extraction of silkworm pupal oil applying the response surface methodology. Bioresource Technol. 100, 4214-4219.

Zacchi, P., Daghero, J., Jaeger, P., Eggers, R. 2006. Extraction/fractionation and deacidification of wheat germ oil using supercritical carbon dioxide. Braz J. Chem. Eng. 23, 105-110.

Zhang, S., Zu, Y., Fu, Y., Luo, M., Liu, W., Li, J., Efferth, T.2010. Supercritical carbon dioxide extraction of seed oil from yellow horn (Xanthoceras sorbifolia Bunge.) and its anti-oxidant activity. Bioresource Technol. 101, 2537-2544.

Zhu, K.X., Zhou, H.M., Qian, H.F. 2006. Proteins extracted from defatted wheat germ: Nutritional and structural properties. Cereal Chem. 83, 69-75. 